\title{
The Relationship Between Company Returns and Leverage Depending on the Business Sec- tor: Empirical Evidence from the Czech Republic
}

\author{
- Strýčková Lenka
}

\begin{abstract}
The paper aims to provide up-to-date empirical evidence of relationship between the key indicators of business competitiveness: leverage and corporate performance. The study is based on corporate financial data of selected companies from the Czech Republic within 14 major business sectors according to CZ-NACE which companies published for the year 2014. The results of this study show that leverage (debt ratio) has a substantially negative effect on corporate performance when the return on equity (ROE) is used as an indicator of corporate performance in the Czech Republic over the period covered by the study. The results of the regression analysis confirmed negative relationship between the company profitability and the use of debt in majority of business sectors (Agriculture, fishery, and forestry; Construction, Wholesale and retail trade, repair of motor vehicles and motorcycles; Professional, scientific and technical activities; Administrative and support service activities). The opposite relationship was found in one business sector only (Mining and quarrying) where positive relationship between the company profitability and leverage was confirmed. Among other things, the results of this study confirm that corporate leverage varies across industries.
\end{abstract}

Keywords: business sector, company, debt, leverage, return

JEL Classification: $G 32$

\section{INTRODUCTION TO COMPANY RETURNS, LEVERAGE AND BUSINESS SECTOR}

In today's globalised world, business performance represents one of the most important indicators measuring how successful and competitive a company is. Business performance should be measured in order to keep the company successful in current and future time as well. The key task is to set properly the indicators measuring the business performance. To fulfil this task, especially financial indicators are usually used. This study uses traditional measure of financial performance, i. e. return on equity (ROE).

Fryndenberg (2011) states that high return on equity is a result of low indebtedness. This argument is economically grounded in the pecking order theory hypothesis, where firms prefer financing through retained earnings to debt financing. Although profitable companies could increase their indebtedness in order to take advantage of the tax shield, empirical studies usually do not confirm this. A negative impact of indebtedness on business profitability is a major argument against the validity of the trade-off theory. 
Leverage refers to financing methods of a company and its ability to meet its financial obligations, and is measured by the debt ratio (total debt to total assets ratio), the debt to equity ratio, and the profit effect of financial leverage.

The pros and cons of corporate debt have already been thoroughly analyzed by many authors. Bernanke (1989) studied the topic from both the microeconomic and the macroeconomic perspectives. His argument for a higher leverage is that it imposes discipline on managers of the corporation, leading to a greater efficiency; higher levels of debt may increase the willingness of insiders to work hard and make profit-maximizing decisions. On the other hand, a higher leverage increases bankruptcy risk. Bernanke emphasized the difference between the microeconomic and macroeconomic perspectives; from the latter, we are concerned not only with the effects of financial distress on the distressed firm itself, but also with the effects of the distressed firm's actions on other firms.

Many empirical studies examined the relationship between company returns and leverage. Those studies use various business performance and leverage measures, and attempt to define the mutual relationship between the returns and the use of debt by statistical methods, by the regression analysis in particular. The individual performance measures usually represent the dependent variable and selected measures of leverage represent the independent variables. The comparability of the results of these studies is further significantly reduced by the use of different statistical samples and different methodologies. Therefore, studies that confirm a negative relationship of profitability and indebtedness as well as studies confirming a positive relationship can be found among empirical studies around the world.

Majority of conducted empirical studies found a negative relationship between company returns and leverage. For example, Arditti (1967), Hall and Weiss (1967), Baker (1973), Breadley, Jarell and Kim (1984), Friend and Lang (1988), Rajan and Zingales (1995), Hutchinson, Hall and Michaelas (1998), Hull (1999), Michaelas, Chittenden and Poutziouris (1999), Bevan and Danbolt (2002), Nissim and Penman (2003), Chen (2004), Delcoure (2007), George and Hwang (2009), Kayo and Kimura (2011), Korkmaz (2016). George and Hwang (2009) found a significant negative relationship between leverage and stock returns, and primarily emphasized the dependence on the business sector.

On the other hand, several studies found a positive relationship between leverage and returns and showed that returns increase with leverage, e.g. Hamada (1969), Masulis (1983), Bhandari (1988), Weill (2004), Brav (2009). The conflicting empirical evidence may result from using different definitions of leverage, stock returns, methodologies, and samples (Muradoglu and Sivaprasad, 2011).

Chadha and Sharma (2015) analyzed the impact of capital structure or financial leverage on firm financial performance on a sample of 422 listed Indian manufacturing companies on Bombay Stock Exchange (BSE). They found out that financial leverage has no impact on the firm's financial performance parameters of return on asset and Tobin's Q. However, they revealed a negative and significant correlation with return on equity.

The findings of foreign studies cannot be unreservedly applied to Czech environment because the Czech Republic has undergone different historical development. However, the Czech expert 
literature on the corporate financing usually takes over conclusions of the foreign publications. Recently, several empirical studies have been conducted even in the Czech Republic.

Krauseova (1995) was among the first authors who analyzed the capital structure of Czech companies depending on the external environment, relating mainly to the historical development since 1989 and the European recession period. In her empirical study, she also analysed the effects of property turnover, profitability, growth, size, and profit volatility on the debt levels according to particular business sectors. She emphasizes a conservative attitude of companies towards debt and predominant accumulation of equity. She also points out a low use of bonds as a source of financing. She predicts that there will be an increase in proportion of debt sources used by Czech companies in the near future. The results of this study confirmed major differences in corporate indebtedness across various business sectors. The relationship between company returns and leverage was not statistically tested.

Bauer (2004) examines the correlation of indebtedness with the company size, industry, profitability, liquidity of assets, growth opportunities, tax rates, tax shield and volatility in his study. First, he focuses on cross-country comparison of corporate leverage and other factors, including ROA. According to this comparison, the leverage of Czech companies measured in book values is relatively low, but leverage measured in the market values can be higher. The author did a regression analysis between leverage and ROA, but no statistically important relationship was confirmed.

The relationship between the debt ratio, long term debt and return on assets was tested by Prasilova (2012). A statistical linear regression revealed a negative relationship between ROA and the debt ratio which corresponds with conclusions of the pecking order theory. The strength of relationship varies in individual industrial sectors. No statistically important relationship was found between ROA and the long term debt.

To determine links between corporate leverage and financial performance of agricultural enterprises, Aulova (2012) compiled and applied an integral performance indicator based on the index IN 95, Altman index, Gurcik index and CH-index. The purpose of this indicator was to eliminate the shortcomings of individual sub-indicators. No relationship between the use of debt and profitability was revealed in the sample of agricultural companies selected.

Steklá et al. (2015) analyzed development of the capital structure and capital disparity across the farmers' cooperatives from fourteen regions of the Czech Republic during the financial and economic crisis $(2009$ - 2013). They found out that the financial and economic crisis lowered the debt to equity ratio and debt to assets ratio and the profitability ratios as well, and the indicators reported the V-shaped trend. The impact of the capital structure indicators on profitability of cooperatives did not prove to be not significant during the period monitored.Firms operating in the same industrial sector tend to have similar external conditions for their business activities. Therefore, it is also possible to find a correlation between the business sector and the capital structure of companies - as shown, for example, by Bradley, Jarrell and Kim (1984). At the same time, the average indebtedness may be a factor that influences the indebtedness of a particular company: Chevalier (1995) found out that individual companies compare their own debt ratios with industry averages and directly (by setting target debt levels) or indirectly adjust their own financial policy to these averages. 
Talberg et al. (2008) dealt with the debt within a particular industrial sector and discovered the differences within individual industries. He explains these inter-sectoral differences in a capital structure by a different level of risk within industries. In accordance with the theory of financial distress, the company with higher risk levels should get less indebted.

\section{METHODOLOGY}

The main objective of this paper is to analyze the impact of leverage on profitability of companies located in the Czech Republic with respect to the business sector.

The study combines a descriptive and an analytical approach. It was conducted with the help of analysis of scientific publications and research papers on the basis of which the literature overview was compiled. The empirical research is based on the statistical analysis. The statistical population was represented by all business companies in the Czech Republic. The corporate financial data used in this study were obtained from the commercial database MagnusWeb which covers all economic subjects in the Czech Republic. The sample was constructed on the basis of the following criteria: a legal entity, an economically active company, the legal form of a joint stock company, the availability of financial data for the year 2014. By means of these filters, it was managed to obtain data related to about 10,000 companies from all regions of the Czech Republic. Incomplete financial data and extreme values in the sample were eliminated. The sample after adjustment used for the statistical evaluation consisted of 7,330 companies. The sample included companies from 14 business sectors classified according to CZ-NACE.

To measure leverage, this study uses the debt ratio which indicates a relative amount of corporate debt in proportion to the assets of a company. The debt ratio is calculated by dividing total liabilities (i.e. long-term and short-term liabilities) by total assets. It indicates what proportion of equity and debt the company is using to finance its assets, or in other words, it measures the percentage of funds provided by creditors (Brigham and Houston, 2013).

Return on equity (ROE) was selected in this study as a measure of financial performance. This ratio is widely used in practice because it poses a simple concept to identify problem areas of the company and their subsequent adjustment on the basis of systematic work with financial statements. Return on equity is calculated by dividing net income by total owner's equity. It indicates how much profit the company generates for the owners based on their ownership claim (Brooks, 2013). Nevertheless, it should be noted that there are several shortcomings of this ratio. The indicator is based on historical data; it does not take into account the problem of risk, the amount of initial invested capital or the future revenues.

\section{EVALUATION OF THE SAMPLE - DESCRIPTIVE STATISTICS}

Tab. 1 and Tab. 2 offer the insight into basic descriptive statistics and quantile values of the debt ratio. The average debt level of the companies included in the sample is $42.7 \%$ if described by mean; $40.3 \%$ if described by median. 
Tab. 1 - Evaluation of the sample - descriptive statistics: the debt ratio. Source: Own investigation.

\begin{tabular}{|l|c|c|c|c|c|c|c|}
\hline $\begin{array}{l}\text { Number of } \\
\text { companies }\end{array}$ & Mean & $\begin{array}{c}\text { Standard } \\
\text { Deviation }\end{array}$ & \multicolumn{2}{|c|}{$\begin{array}{c}95 \% \text { confidence } \\
\text { interval }\end{array}$} & Median & Min & Max \\
\hline 7330 & 0.427 & 0.2886 & 0.420 & 0.434 & 0.403 & 0.000 & 0.995 \\
\hline
\end{tabular}

Tab. 2 - Table of the quantile values: the debt ratio. Source: Own investigation.

\begin{tabular}{|l|l|l|l|l|l|l|l|l|l|}
\hline Quantile & Min. & $0.5 \%$ & $2.5 \%$ & $25.0 \%$ & $50.0 \%$ & $75.0 \%$ & $97.5 \%$ & $99.5 \%$ & Max. \\
\hline Value & 0.000 & 0.000 & 0.004 & 0.171 & 0.403 & 0.664 & 0.954 & 0.985 & 0.995 \\
\hline
\end{tabular}

The total debt ratio is represented by a statistically significant declining trend ( $\mathrm{p}$-value $\leq 9 \times 10$ 6 ) in the interval between 0 and 1 . The distribution is substantially uniform, as seen from the distraction diagram (Fig. 1).

Fig. 1 with histogram of the debt ratio provides a more detailed analysis of distribution of values.

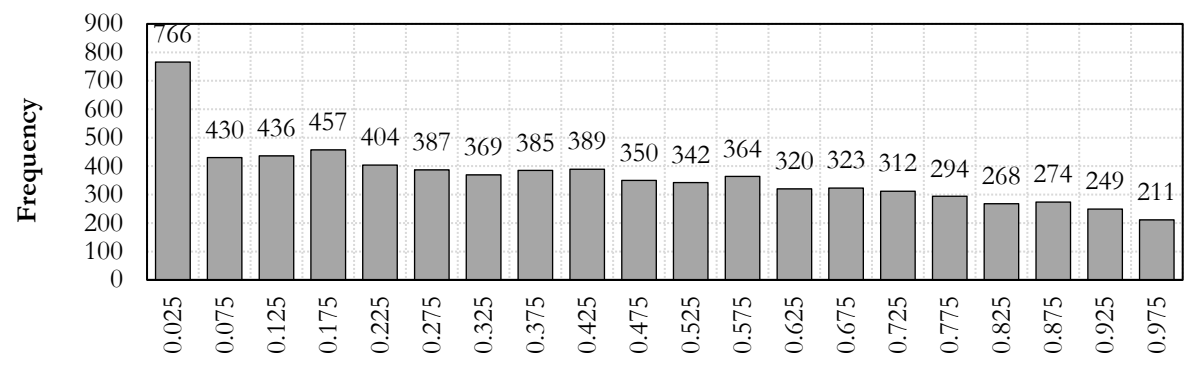

Debt ratio values

Fig. 1 - Histogram of the debt ratio. Source: Own investigation.

Tab. 3 and Tab. 4 illustrate the descriptive statistics and quantile values of the ratio ROE. Profitability of the companies included in the sample is on a low level, which is demonstrated by average values of return on equity: mean is even negative (-0.024), median is 0.044 . It is apparent that the sample contains outlier data (minimum -84, etc.). Nevertheless, $95 \%$ of the data lies within the interval $<-0.84 ; 0.718>$. Negative values of ROE indicate a negative net income or a financial loss. On the other hand, if a firm reports a negative net income, it doesn't always mean that it is a bad investment. Free cash flow is another form of profitability and can be used in lieu of the net income. The second eventuality when ROE is negative is when the value of equity is negative which is generally a sign of a firm going bankrupt. However, some problems could appear in interpreting ROE when the value of equity is negative and the net income is negative. ROE would be positive then and it has no economic or financial meaning, and those records were excluded from the database. 
Tab. 3 - Evaluation of the sample - descriptive statistics: ROE. Source: Own investigation.

\begin{tabular}{|l|c|c|c|c|c|c|c|}
\hline $\begin{array}{l}\text { Number of } \\
\text { companies }\end{array}$ & Mean & $\begin{array}{c}\text { Standard } \\
\text { Deviation }\end{array}$ & \multicolumn{2}{|c|}{$\begin{array}{c}95 \% \text { confidence } \\
\text { interval }\end{array}$} & Median & Min & Max \\
\hline 7330 & -0.024 & 2.128 & -0.073 & 0.024 & 0.044 & -84.638 & 14.586 \\
\hline
\end{tabular}

Tab. 4 - Table of the quantile values: ROE. Source: Own investigation.

\begin{tabular}{|l|c|c|c|c|c|c|c|c|c|}
\hline Quantile & Min. & $0.5 \%$ & $2.5 \%$ & $25.0 \%$ & $50.0 \%$ & $75.0 \%$ & $97.5 \%$ & $99.5 \%$ & Max. \\
\hline Value & -84.638 & -4.04 & -0.84 & -0.002 & 0.044 & 0.144 & 0.718 & 1.695 & 14.586 \\
\hline
\end{tabular}

Fig. 2 presents a histogram of ROE in the sample. The distribution of ROE values appears to be shifted towards positive values. Based on this slope, it can be stated that the mean value is significantly different from zero ( $\mathrm{p}$-value of Wilcoxon test is $\leq 2,2 \mathrm{x} 10-16$ ).

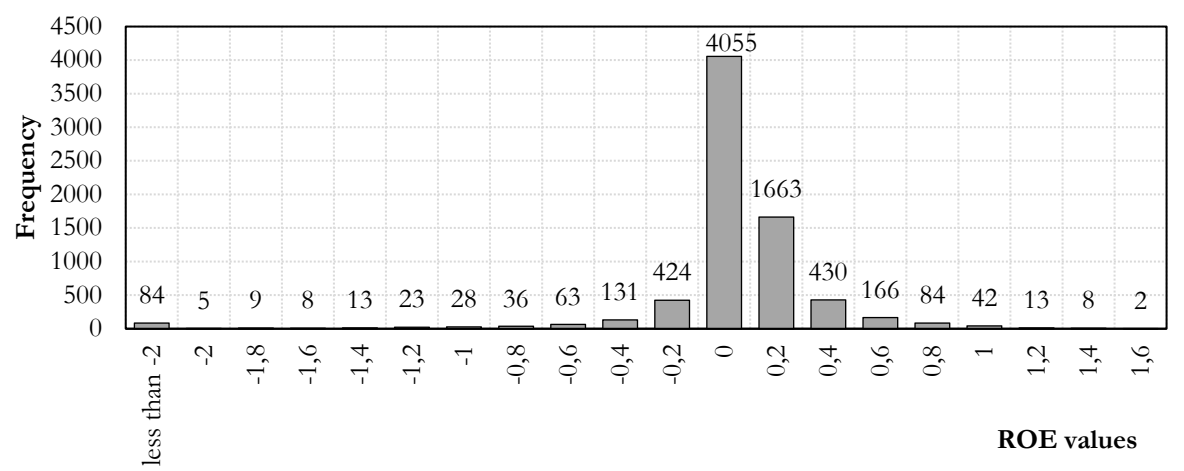

Fig. 2 - Histogram of ROE. Source: Own investigation.

\section{RESEARCH RESULTS}

The interaction between company return and leverage was tested by the linear regression model. ROE was set as the dependent variable, and as the independent variable, the debt ratio was set.

The sample of companies was divided into 14 business sectors classified according to CZ-NACE (categories A to N). For each category (business sector) following the regression model was investigated:

$\mathrm{ROE}=a_{0}+a_{1} \times$ debt ratio

Tab. 5 summarizes estimations of individual parameters of regression functions for above- mentioned model according to categories of the business sector. The meaningfulness of a regression can be considered only if the parameter a1 proves to be statistically significant. It can be considered as statistically significant only if the $\mathrm{p}$-value is $\leq 0.05$. Only in such case, there can be expected a relevant change of ROE in relation to the change of the debt ratio. If both parameters $\left(a_{0}\right.$ and $\left.a_{1}\right)$ are statistically significant, there is a classical regression line with a shift in the ordinate by the value of $\mathrm{a}_{0}$. If the parameter $a_{0}$ is statistically insignificant, the statement that the regres- 
sion line passes through the origin (i.e. if the value of the debt ratio is 0 , then the value of ROE is also 0 ) cannot be rejected

Tab. 5 - Estimation of parameters by linear regression according to the business sector. Source: Own investigation

\begin{tabular}{|c|c|c|c|c|c|}
\hline Business sector & $\begin{array}{l}\text { Number of } \\
\text { companies }\end{array}$ & $\begin{array}{l}\text { Parameter } \\
\mathrm{a}_{0}\end{array}$ & $\begin{array}{c}\mathrm{p} \text {-value } \\
\mathrm{a}_{0}\end{array}$ & $\begin{array}{c}\text { Parameter } \\
a_{1}\end{array}$ & $\begin{array}{c}\mathrm{p} \text {-value } \\
\mathrm{a}_{1}\end{array}$ \\
\hline $\begin{array}{l}\text { A - Agriculture, fishery, and } \\
\text { forestry }\end{array}$ & 562 & 0.1096 & 0.0000 & -0.1506 & 0.0146 \\
\hline B - Mining and quarrying & 31 & -0.1657 & 0.0784 & 0.7802 & 0.0008 \\
\hline $\mathrm{C}$-Manufacturing & 1240 & 0.1412 & 0.3248 & -0.4013 & 0.1597 \\
\hline $\begin{array}{l}\text { D - Electricity, gas, steam and } \\
\text { air conditioning }\end{array}$ & 174 & 0.0295 & 0.7682 & 0.0664 & 0.6739 \\
\hline $\begin{array}{l}\text { E - Water supply; sewerage, } \\
\text { waste management and reme- } \\
\text { diation activities }\end{array}$ & 142 & 0.0959 & 0.0647 & -0.0731 & 0.5087 \\
\hline $\mathrm{F}$ - Construction & 562 & 0.1375 & 0.0030 & -0.2025 & 0.0158 \\
\hline $\begin{array}{l}\text { G - Wholesale and retail } \\
\text { trade; repair of motor vehicles } \\
\text { and motorcycles }\end{array}$ & 1180 & 0.3398 & 0.0599 & -0.9346 & 0.0034 \\
\hline $\begin{array}{l}\mathrm{H}-\text { Transportation and stor- } \\
\text { age }\end{array}$ & 176 & 0.1025 & 0.1407 & -0.0362 & 0.7873 \\
\hline $\begin{array}{l}\text { I - Accommodation and food } \\
\text { service activities }\end{array}$ & 139 & -0.0574 & 0.7793 & 0.4850 & 0.2207 \\
\hline $\begin{array}{l}\text { J - Information and commu- } \\
\text { nication }\end{array}$ & 258 & 0.1823 & 0.0067 & -0.2530 & 0.0721 \\
\hline $\begin{array}{l}\mathrm{K}-\text { Financial and insurance } \\
\text { activities }\end{array}$ & 247 & 0.1655 & 0.0054 & -0.1557 & 0.1652 \\
\hline $\mathrm{L}$ - Real estate activities & 1377 & 0.0399 & 0.1866 & -0.1181 & 0.0379 \\
\hline $\begin{array}{l}\text { M - Professional, scientific } \\
\text { and technical activities }\end{array}$ & 759 & 0.4015 & 0.0860 & -1.4590 & 0.0021 \\
\hline $\begin{array}{l}\mathrm{N}-\text { Administrative and sup- } \\
\text { port service activities }\end{array}$ & 176 & 0.4112 & 0.1203 & -1.1521 & 0.0233 \\
\hline
\end{tabular}

The results of the analysis conducted demonstrated that the regression model was statistically significant for several business sectors only. Those business sectors were: A - Agriculture, fishery, and forestry, B - Mining and quarrying, F - Construction, G - Wholesale and retail trade; repair of motor vehicles and motorcycles, $\mathrm{M}$ - Professional, scientific and technical activities, and $\mathrm{N}$ - Administrative and support service activities. The parameter $a_{0}$ is indicated as statistically insignificant in majority of business sectors mentioned (the only two exceptions are categories A and F). This means that the statement "if the debt ratio is zero, ROE is also zero" cannot 
be rejected. The highest values of $\mathrm{ROE}$ at zero level of debt ratio are indicated for industries: $\mathrm{M}$ - Professional, scientific and technical activities, N - Administrative and support service activities, and $\mathrm{G}-$ Wholesale and retail trade; repair of motor vehicles and motorcycles.

Fig. 3, Fig. 5, Fig. 6, Fig. 7 and Fig. 8 confirm a negative relationship between the company profitability and the use of debt in the business sectors A, F, G, M, and N. A negative slope of the line indicates that ROE is decreasing as more debt is used.

The only exception is the business sector B (Fig. 4) where the situation is opposite; the value of $\mathrm{ROE}$ is increasing with an increasing value of the debt ratio. A more detailed analysis of this business sector offers possible explanation of positive relationship. According to the data analysis of CRIF Czech Credit Bureau (2017), there was a significant decline in equity in the business sector Mining and quarrying accompanied by a decline in leverage in recent years (2012 - 2015).

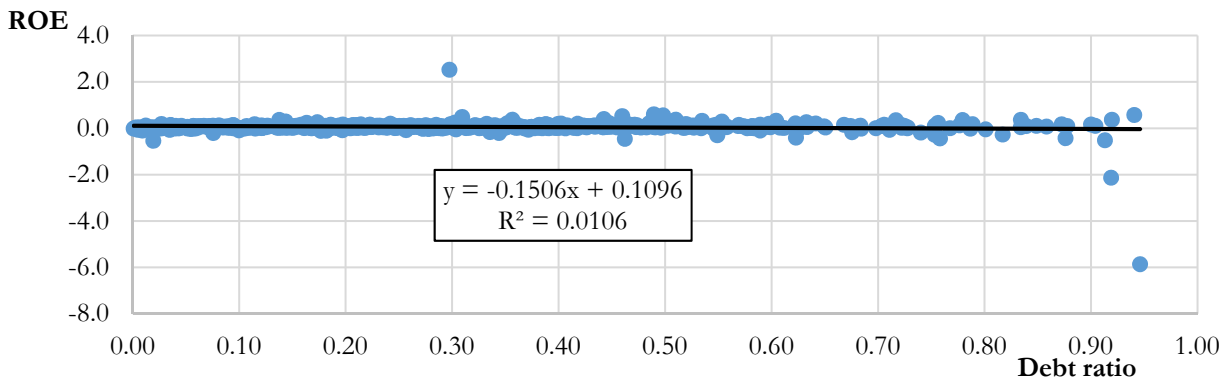

Fig. 3 - Relationship of ROE and debt ratio in the business sector A - Agriculture, fishery, and forestry. Source: Own investigation.

\section{ROE}

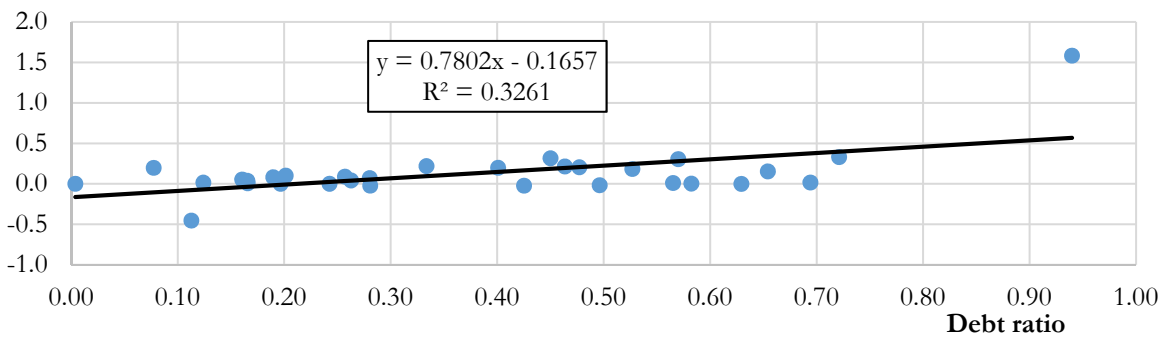

Fig. 4 - Relationship of ROE and debt ratio in the business sector B - Mining and quarrying. Source: Own investigation. 


\section{ROE}

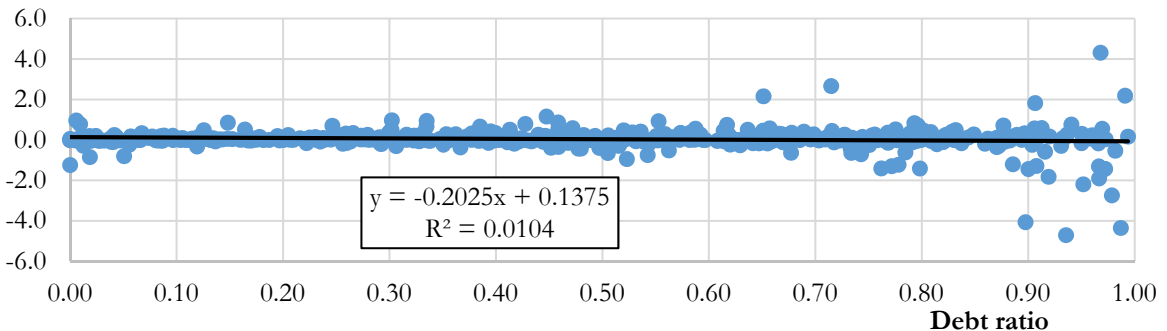

Fig. 5 - Relationship of ROE and debt ratio in the business sector F - Construction. Source: Own investigation.

\section{ROE}

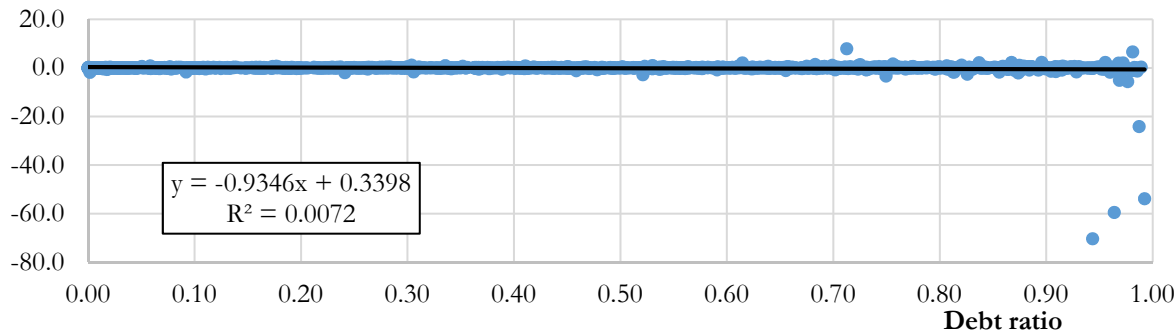

Fig. 6 - Relationship of ROE and debt ratio in the business sector $G$ - Wholesale and retail trade; repair of motor vebicles and motorcycles. Source: Own investigation.

\section{ROE}

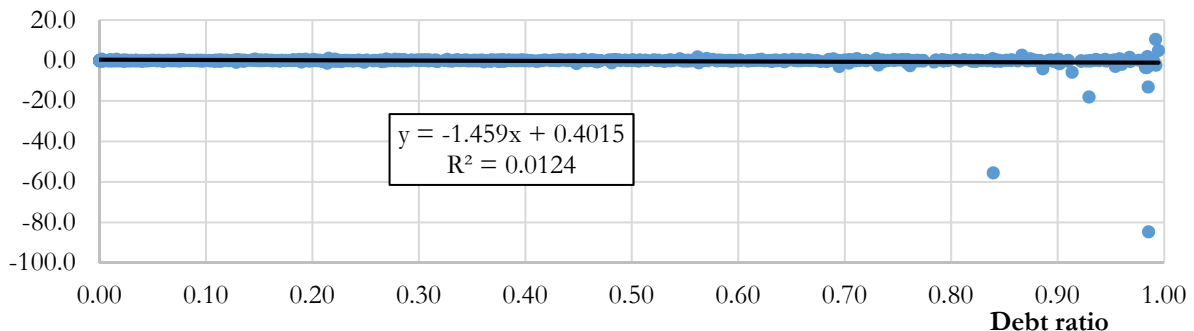

Fig. 7 - Relationship of ROE and debt ratio in the business sector M - Professional, scientific and technical activities. Source: Own investigation. 
ROE

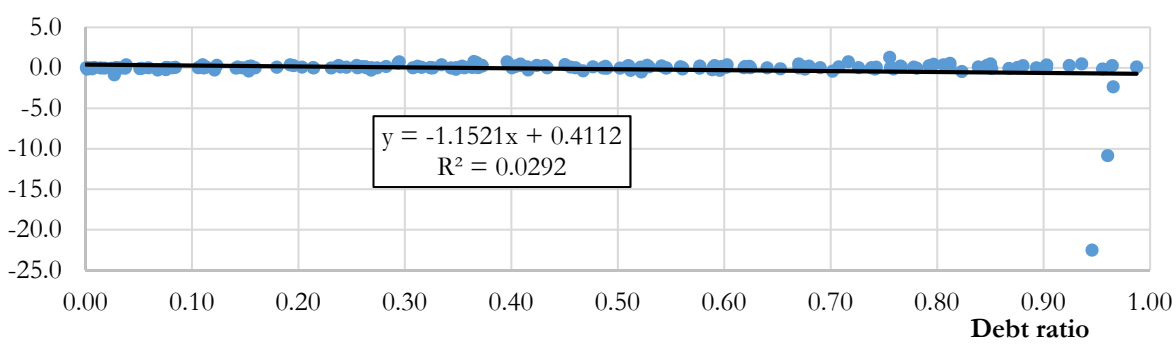

Fig. 8 - Relationship of ROE and debt ratio in the business sector $N$ - Administrative and support service activities. Source: Own investigation.

If the steepness of decline in the value of ROE as a function of the unit change in value of the debt ratio is taken into consideration, the most significant relationship is found by the business sector M - Professional, scientific and technical activities (Fig. 7), which is actually more than ten times higher than by the business sector with the lowest steepness of decline - A - Agriculture, fishery, and forestry (Fig. 3).

\section{CONCLUSIONS}

The main objective of the paper presented was to analyze the impact of leverage on profitability of companies located in the Czech Republic with respect to the business sector. According to the literature, the use of debt can have both positive and negative effects on returns and competitiveness of a company.

The statistical population was represented by all business companies in the Czech Republic. The corporate financial data used in this study were obtained from the commercial database MagnusWeb. The sample after adjustment consisted of 7,330 companies from 14 business sectors classified according to CZ-NACE. The financial data used for analysis in the study were from the year 2014 .

The findings presented in this study demonstrate that leverage (debt ratio) has a substantially negative effect on corporate performance when the return on equity (ROE) is used as an indicator of corporate performance in the Czech Republic over the period covered by the study. The regression model was statistically significant only for six business sectors. However, statistically insignificant values of regression analysis do not have to mean that this relationship is insignificant even practically. The results of the regression analysis confirmed a negative relationship between the company profitability and the use of debt in majority of business sectors: A - Agriculture, fishery, and forestry, F - Construction, G - Wholesale and retail trade; repair of motor vehicles and motorcycles, $\mathrm{M}$ - Professional, scientific and technical activities, and N - Administrative and support service activities. This finding is in accordance with majority of conducted empirical studies, as listed in the literature.

Only in the business sector B - Mining and quarrying, the situation was opposite, and a positive relationship between the company profitability and leverage was confirmed. 
Another important finding of this study is confirmation of the theoretical assumption of differences in the approach of companies to debt within individual industries.

With respect to the specifics of business financing and economic environment in the Czech Republic, the findings of foreign studies should not be unreservedly applied to companies located in the Czech Republic. This study attempted to contribute and to enhance the Czech expert literature in the field of corporate financing, which can be seen as an important benefit of it.

Based on the evaluation of the study results, we can conclude that no significant differences in relationship between company leverage and returns were found (business sectors in particular), in comparison to the results of foreign studies.

Of course, there are also research limitations. The sample was large enough for the analysis, but the selection of business performance and leverage measures offers space for discussion. As a possible shortcoming of this study could be seen the use of ROE and the debt ratio to demonstrate relationship between the financial performance and leverage, as in already conducted studies, there are used various measures of business performance and leverage. Therefore, the perfect comparability of conclusions is not entirely possible. Further research could therefore be focused on covering a longer time horizon or on different measures of leverage and profitability.

\section{References}

1. Arditti, F. D. (1967). Risk and the required return on equity. The Journal of Finance. 22(1), 1936. DOI: 10.1111/j.1540-6261.1967.tb01651.x.

2. Aulová, R. (2012). Kapitálová struktura zemédělskéch podnikei a její determinanty. Praha: Česká zemědělská univerzita v Praze. Disertační práce.

3. Baker, S. H. (1973). Risk, Leverage and Profitability: An Industry Analysis. Review of Economics and Statistics. 55(4), 503-507. DOI: 10.2307/1925675.

4. Bauer, P. (2004). Determinants of capital structure: empirical evidence from the Czech Republic. Finance a úvér. 54(1/2), 2-21.

5. Bernanke, B. (1989). Is there too much corporate debt? Business Review, Federal Reserve Bank of Philadelphia. 3-12.

6. Bevan, Alan A. \& Danbolt, J. (2002). Capital structure and its determinants in the United Kingdom - a decompositional analysis. Applied Financial Economics. 12(3), 159-170. DOI: 10.2139/ssrn.233550.

7. Bhandari, L. C. (1988). Debt/Equity Ratio and Expected Common Stock Returns: Empirical Evidence. Journal of Finance. 43(2), 507-528. DOI: 10.1111/j.1540-6261.1988. tb03952.x.

8. Bradley, M., Jarrell, G. A. \& Kim, E. H. (1984). On the Existence of an Optimal Capital Structure: Theory and Evidence. The Journal of Finance. 39(3), 857-878. DOI: 10.1111/j.15406261.1984.tb03680.x.

9. Brav, O. (2009). Access to Capital, Capital Structure, and the Funding of the Firm. The Journal of Finance. 64(1), 263-308. DOI: 10.1111/j.1540-6261.2008.01434.x. 
10. Brigham, E. F. \& Houston, J. F. (2013). Fundamentals of financial management. Mason, Ohio: South-Western Cengage Learning.

11. Brooks, R. (2013). Financial management: core concepts. Boston: Pearson.

12. CRIF Czech Credit Bureau (2017). Firmy v uplynulých letech zvysovaly vlastni keapitál a krátkodobý finančni majetek. http://www.informaceofirmach.cz/firmy-v-uplynulych-letech-zvysovalyvlastni-kapital-a-kratkodoby-financni-majetek/

13. Delcoure, N. (2007). The determinants of capital structure in transitional economies. International Review of Economics and Finance. 16(3), 400-415. DOI: 10.1016/j.iref.2005.03.005.

14. Friend, I. \& Lang, L. (1988). An empirical test of the impact of managerial self-interest on corporate capital structure. The Journal of Finance. 43(2), 271-281. DOI: 10.1111/j.15406261.1988.tb03938.x.

15. Frydenberg, S. (2011). Capital Structure Theories and Empirical Tests: An Overview. Capital Structure and Corporate Financing Decisions. Hoboken, NJ, USA: John Wiley, pp. 127. DOI: 10.1002/9781118266250.ch8.

16. George, T. J. \& Hwang, Ch. Y. (2010). A resolution of the distress risk and leverage puzzles in the cross section of stock returns. Journal of Financial Economics. 96(1), 56-79. DOI: 10.1016/j.jfineco.2009.11.003.

17. Hall, M. \& Weiss, L. (1967). Firm Size and Profitability. Review of Economics and Statistics. 49(3), 319-331.

18. Hamada, R. S. (1969). Portfolio Analysis, Market Equilibrium and Corporation Finance. Journal of Finance. 24(1). 13-31. DOI: 10.1111/j.1540-6261.1969.tb00339.x.

19. Hull, R. M. (1999). Leverage Ratios, Industry Norms, and Stock Price Reaction: An Empirical Investigation of Stock-for-Debt Transactions. Financial Management. 25(2), 32-45.

20. Hutchinson, P., Hall, G. \& Michaelas, N. (1998). The determinants of capital structure for micro, small and medium-sized enterprises. Working Paper.

21. Chadha, S. \& Sharma, A. K. (2015). Capital Structure and Firm Performance: Empirical Evidence from India. Vision; Gurgaon. 19(4), 295-302. DOI: 10.1177/0972262915610852.

22. Chen, J. J. (2004). Determinants of capital structure of Chinese-listed companies. Journal of Business Research. 57(12), 1341-1351. DOI: 10.1016/S0148-2963(03)00070-5.

23. Chevalier, J. A. (1995). Do LBO Supermarkets Charge More? An Empirical Analysis of the Effects of LBOs on Supermarket Pricing. The Journal of Finance. 50(4), 1095-1112. DOI: 10.1111/j.1540-6261.1995.tb04051.x.

24. Kayo, K. E. \& Kimura, H. (2011). Hierarchical determinants of capital structure. Journal of Banking \& Finance. 35(2), 358-371. DOI: 10.1016/j.jbankfin.2010.08.015.

25. Korkmaz, Ö. (2016). The Effects of Profitability Ratios on Debt Ratio: the Sample of the BIST Manufacturing Industry. Financial Studies. 20(2), 35-54.

26. Krauseová, J. (1995). Analýza kapitálové struktury českých firem. Finance a úvěr. 45(9), 481491. 
27. Masulis, R. W. (1983). The Impact of Capital Structure Change on Firm Value: Some Estimates. The Journal of Finance. 38(1), 107-126. DOI: 10.1111/j.1540-6261.1983.tb03629.x.

28. Michaelas, N., Chittenden, F. \& Poutziouris, P. (1999). Financial Policy and Capital Structure Choice in U. K. SMEs: Empirical Evidence from Company Panel Data. Small Business Economics. 12(2), 113-130. DOI: 10.1023/A:1008010724051.

29. Muradoglu, Y.G. \& Sivaprasad S. (2011). Using Firm'Level Leverage as an Investment Strategy. Journal of Forecasting. 31(3), 260-279.

30. Nissim, D. \& Penman, S. H. (2003). Financial Statement Analysis of Leverage and How It Informs About Profitability and Price-to-Book Ratios. Review of Accounting Studies. 8(4), 531 560. DOI: 10.1023/A:1027324317663.

31. Prášilová, P. (2012). Determinanty kapitálové struktury českých podniků. E + M. Ekonomie a Management: Economics and Management. 15(1), 89-104.

32. Rajan, R. G. \& Zingales, L. (1995). What Do We Know About Capital Structure? Some Evidence from International Data. The Journal of Finance. 50(2), 1421-1459. DOI: 10.1111/ j.1540-6261.1995.tb05184.x.

33. Steklá, J., et al. (2015). 34. Evaluation of Capital Structure of Agricultural Cooperatives. Agris on-line Papers in Economics and Informatics. 7(3), 37-48.

34. Talberg, M., et al. (2008). Capital Structure Across Industries. International Journal of the Economics of Business. 15(2), 181-200. DOI: 10.1080/13571510802134304.

35. Weill, L. (2004). What Determines Leverage in Transition Countries. Finance a úvèr - Czech Journal of Economics and Finance. 54(5-6), 234-242.

\section{Contact information}

Ing. Lenka Strýcková, Ph.D.

Technical University of Liberec, Faculty of Economics, Department of Finance and Accounting

Studentská 2, 46117 Liberec 1, Czech Republic

Email:lenka.stryckova@tul.cr. 